\title{
Comparative study of the effects of two programs of physical exercises in flexibility and balance of healthy elderly individuals with and without major depression
}

\author{
Estudo comparativo dos efeitos de dois programas de exercícios físicos na flexibilidade e no \\ equilíbrio em idosos saudáveis com e sem depressão maior
}

Fernanda Varkala Lanuez ${ }^{1}$, Wilson Jacob-Filho', Mariana Varkala Lanuez ${ }^{1}$, Ana Cláudia Becattini de Oliveira ${ }^{1}$

\begin{abstract}
Objective: To assess flexibility and balance in healthy elderly subjects with or without major depression, by means of two different programs: aerobic exercises and flexibility and balance exercises. Methods: A randomized, double-blind controlled study in which each sample was the control of itself. Research subjects were 19 healthy elderly individuals, aged between 60 and 90 years, of both genders, referred to the Department of Geriatrics of the Hospital das Clínicas da Faculdade de Medicina da Universidade de São Paulo, with or without the diagnosis of major depression, and sedentary or that had not engaged in physical activity for at least 6 months. Results: Subjects with major depression, as well as those without depression, showed significant improvement in flexibility and balance, especially in the group that did aerobic exercises. Conclusion: The results of this investigation reinforce the relevance of physical exercises for the elderly with major depression, as this is an important tool for treating and following-up this group of patients.
\end{abstract}

Keywords: Exercise; Aged; Pliability; Postural balance; Depression

\section{RESUMO}

Objetivo: Avaliar a flexibilidade e o equilíbrio em idosos saudáveis com ou sem depressão maior, por meio de dois diferentes programas: prática de exercícios aeróbios e realização de exercícios de flexibilidade e equilíbrio. Métodos: Estudo randomizado, duplo-cego, ensaio controlado, no qual cada amostra foi controle dela mesma. Foram sujeitos dessa pesquisa 19 idosos, com idades entre 60 e 90 anos, de ambos os sexos, encaminhados dos ambulatórios do Serviço de Geriatria do Hospital das Clínicas da Faculdade de Medicina da Universidade de São Paulo, saudáveis com ou sem o diagnóstico de depressão maior, sedentários ou que não tivessem praticado atividade física por pelo menos 6 meses. Resultados: Observou-se que os idosos com depressão maior obtiveram melhora expressiva da flexibilidade e do equilíbrio, assim como os não deprimidos, principalmente no grupo que realizou exercício aeróbio. Conclusão: Os resultados desta investigação reforçam a relevância da prática de exercícios físicos pelos idosos com depressão maior, sendo este um importante instrumento no tratamento e acompanhamento desse grupo de pacientes.

Descritores: Exercício; Idoso; Maleabilidade; Equilíbrio postural; Depressão

\section{INTRODUCTION}

The prevalence of depressive symptoms in the aged is significantly greater than the presence of major depression $^{(1)}$. In Brazil, it is estimated that about $8 \%$ of the elderly present with episodes of major depression and $23 \%$ of depressive symptoms, expressed most keenly in women and in the low-income population ${ }^{(2)}$.

Some factors, such as the reduced social perspectives, declining health, frequent losses, and biological, vascular, structural, and functional alterations, besides neuroendocrine and neurochemical dysfunctions that occur in the brain during aging, contribute to the appearance of depressive symptoms in the elderly. Thus, the development of depression in the aged has a fundamentally multifactorial character ${ }^{(3)}$.

Major depressive disorder is classified as a type of more serious depression that presents the greatest risk of suicide. It is an endogenous depression due to less activity of cerebral monoamines ${ }^{(4)}$.

Study carried out at Department of Geriatrics, Hospital das Clínicas, Faculdade de Medicina, Universidade de São Paulo - USP, Sao Paulo (SP), Brazil.

' Department of Geriatrics, Hospital das Clínicas, Faculdade de Medicina, Universidade de São Paulo - USP, Sao Paulo (SP), Brazil.

Corresponding author: Fernanda Varkala Lanuez - Universidade Nove de Julho, Coordenação do Curso de Fisioterapia - Rua Liberdade, 235/249 - CEP 01504-001 - São Paulo (SP), Brasil - E-mail: fervarkala@hotmail.com

Received on: Jul 24, 2010 - Accepted on: Aug 5, 2011

Conflicts of interest: none 
It is known that the natural biological process of aging determines alterations in motor control ${ }^{(5)}$. Alterations such as the widening of the base of support, decrease in length and height of steps, reduction in velocity, decrease in the extension of knees and hips, besides modifications in flexibility and balance that manifest as abnormal gait patterns, and fundamental ability for locomotion. These manifestations are responsible for limiting movement and elevating the rate of sedentarism of this population that ages ${ }^{(6-8)}$.

Depressed elderly persons present with a decline in self-care, refusing to feed themselves and to follow the clinician's recommendations, and thus remain for longer periods of time restricted to their beds or with little physical mobility. These factors, associated with general clinical debility, enhance decrease in the functional capacity related to age, considerably hindering the performance of daily life activities and of quality of life ${ }^{(9)}$.

Physical activity performed in a regular and systematic manner is recognized as a strong ally in the process of aging, easing changes such as decreased muscle strength, equilibrium, flexibility, and aerobic resistance ${ }^{(10)}$. Several studies have pointed out the influence of systematic physical exercises engaged in regularly to control and improve depressive symptoms in the elderly ${ }^{(9)}$.

The present study confronts two forms of physical activity in determining motor aptitude in the aged with major depression.

\section{OBJECTIVES}

To assess flexibility and balance in the elderly with or without major depression as well as the effects of two different physical exercise programs on two randomized groups of aged persons with major depression.

\section{METHODS}

An interventional, controlled, randomized study with correlated samples in which each group was the control for itself, with duration of 12 months, approved by the Research Ethics Committee of the Hospital das Clínicas da Faculdade de Medicina da Universidade de São Paulo (HC-FMUSP). The study began in February 2002 and ended in February 2003.

Participating in this research were 19 elderly individuals aged between 60 and 90 years, of both genders, sedentary or who had not engaged in any type of physical exercise during the previous 6 months, with or without the diagnosis of major depression, referred to the outpatients clinic of the
Department of Geriatrics of the HC-FMUSP. For the diagnosis of major depression, the following criteria were used: Geriatric Depression Scale $\geq 14$ and criteria for depressive disorders of the Diagnostic and Statistical Manual of Mental Disorders $-4^{\text {th }}$ edition (DSM-IV).

The elderly diagnosed with major depression were medicated with sertraline hydrochloride, with an initial dose of $50 \mathrm{mg}$ starting at the first visit; dose adjustment was made every 6 weeks, with $50 \mathrm{mg}$ increments up until the maximal dose of $150 \mathrm{mg}$. The other elderly subjects, who presented with no depressive symptoms, were accompanied in the outpatient's clinic.

Randomization was carried out by a professional from the team, always in the presence of another member of the team, in the form of a drawing, to divide subjects into two groups:

- Group A: Aerobic Exercises, had monitored walks along the athletics field circuit $(400 \mathrm{~m})$;

- Group B: Flexibility and Balance Exercises, performed active stretching exercises of the lower and upper extremities (stretching of the brachial biceps, brachial triceps, major pectoral, quadriceps, sural triceps, ischiotibial, gluteus maximum) and exercises with progressive modification of the support base and of visual conditions (rising on the tips of the toes with a wide base, which is then diminished, lateralization of the trunk, squatting with widened and then narrowed base, and exercises carried out with their eyes shut).

For both groups, the following activities were performed: warm-up (duration 5 minutes), consisting of circular movements of the lower and upper limbs, head rotation movements and a slow walk around the grass area, and cooling-off period (duration 5 minutes), which was composed of respiratory exercises, by means of which the respiratory patterns associated with elevation of the upper limbs and self-massage were developed, when the participants formed a circle and each one of them massaged the person in front of them.

The activities were developed at the Associação Atlética Acadêmica Osvaldo Cruz (AAAOC), with duration of 50 minutes for each session, for 12 months.

All the elderly signed the Informed Consent Form, of the HC-FMUSP, authorized by the Ethics Committee for Analysis of Research Projects (CAPPesq).

In order to fulfill the objectives of this investigation, evaluation tools were used.

Equilibrium was evaluated by means of the tests:

- modified Romberg: functional test that assesses balance with alterations in the support base, 
body posture, and visual conditions, in which the individuals remain in the established positions for 10 seconds, at the most, and the total score is 10 points $^{(11,12)}$;

- function of the lower extremities test: performance test that evaluated balance during changes in the support base, in speed, and in capacity to walk, with a maximum score of 12 points $^{(13)}$.

Flexibility was evaluated by means of the sit and reach test, or the modified Wells bench test, which is a functional test by means of which flexibility of the trunk and of the lower limbs is evaluated. The individual is positioned sitting on the ground, with the back supported against a wall, lower limbs spread apart $30 \mathrm{~cm}$ and supported on a box $(50 \times 90 \times 30)$. The patient is instructed to extend the upper limbs and to perform flexion of the trunk, obtaining a score in centimeters $^{(14,15)}$.

As exclusion criteria, the parameters utilized by the American College of Sports Medicine (ACSM) were used: subjects with a recent history of acute myocardial infarct, presence of serious aortic stenosis, dissecting aneurysm of the aorta, decompensated congestive heart failure, unstable angina, and recent myocarditis, besides pulmonary embolism or ventricular tachycardia ${ }^{(16)}$.

For the statistical analysis, the SigmaStat 3.1 program for Windows was used, in which the univariate analysis for one factor was used for intra-group comparison (ANOVA 1 Factor). In the inter-group analysis, Dunn's method was used. Results with $\mathrm{p}<0.001$ were considered significant.

\section{RESULTS}

Table 1 represents the demographic data of the 19 elderly participants of the study. The values presented are in mean \pm standard deviation.

Table 1. Characteristics of patients

\begin{tabular}{lcc}
\hline Characteristics & Group A & Group B \\
\hline Patients & 9 & 10 \\
Age (years) & $69.1 \pm 2.14$ & $75.44 \pm 3.00$ \\
Maximum/minimum (years) & $65-72$ & $73-82$ \\
Sex (F/M) & $6 / 3$ & $7 / 2$ \\
\hline
\end{tabular}

F: female; M: male.

Figures 1 and 2 are represented in Box Plot, in which Group A: black - non-depressed; and white - depressed; and in Group B: striped - non-depressed, and dots depressed.

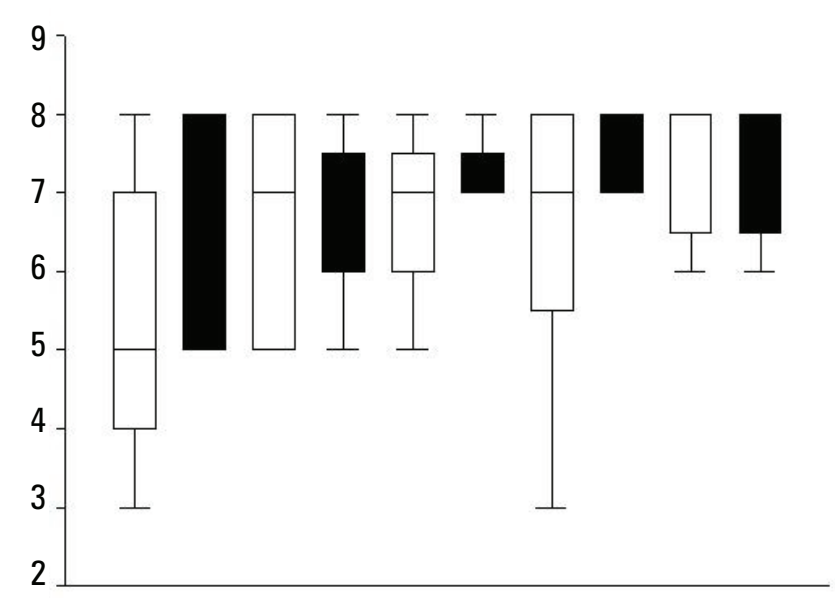

Figure 1. Modified Romberg Group A

In the intra-group analysis, $\mathrm{p}<0.001$ was considered.

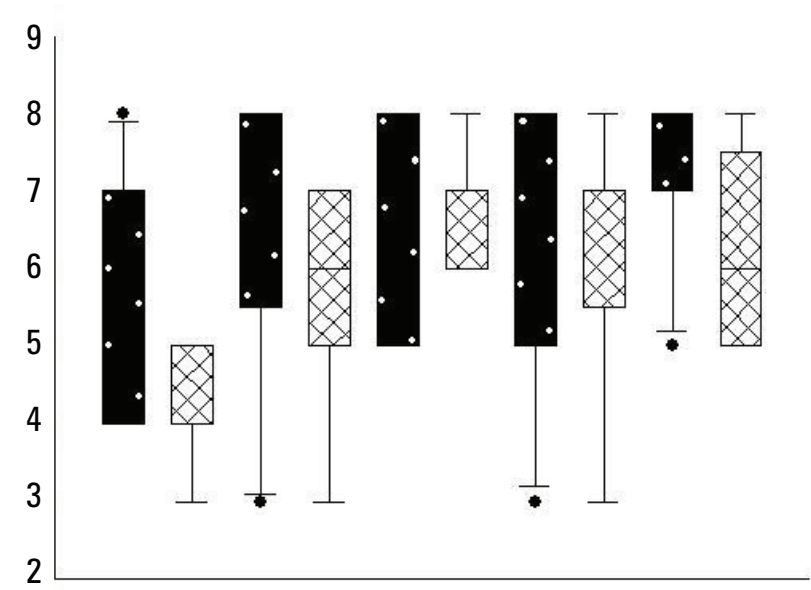

Figure 2. Modified Romberg Group B

In the intra-group analysis, $\mathrm{p}<0.001$ was considered, verifying a significant improvement in the depressed individuals for the parameter studied, both in Group A and in Group B.

In the inter-group analysis, $p>0.05$ was considered and it was noted that the depressed adults of Group A presented with more expressive improvements when compared with the depressed elderly of Group B (Figures 3 and 4), where Group A: black - nondepressed and white - depressed; and in Group B: stripped - non-depressed, and dots - depressed. 


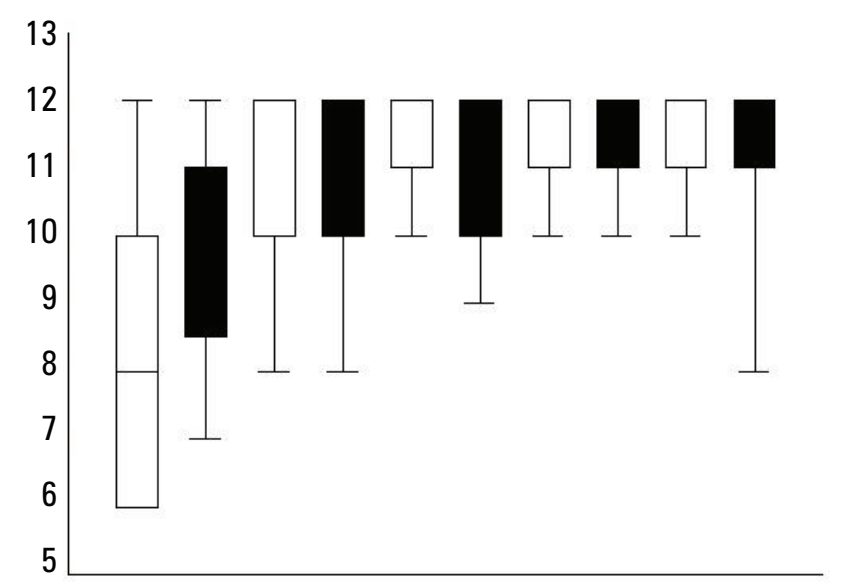

Figure 3. Test of lower limb extremity or Guralnik Group A

In the intra-group analysis $\mathrm{p} \leq 0.001$ was considered, and improvement in the depressed subjects was observed when compared to the non-depressed.

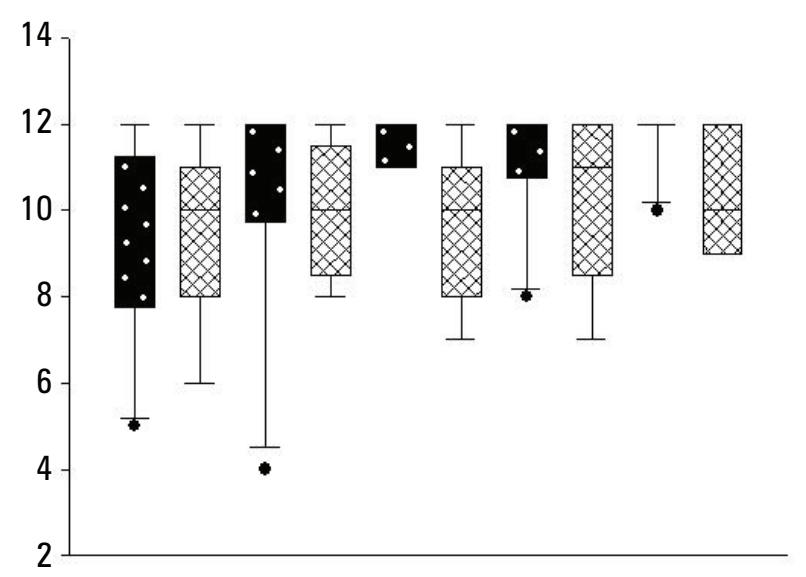

Figure 4. Test of lower limb extremity or Guralnik Group B

The value of $p \leq 0.001$ was considered in the intragroup analysis, and improvement of the depressed subjects was observed when compared with the non-depressed.

In the intra-group analysis, $\mathrm{p} \leq 0.001$ was considered, with an observation of significant improvement in depressed elderly patients for the parameter studied, both in Group A and in Group B, equating them with the non-depressed elderly subjects.

In the inter-groups analysis, $\mathrm{p} \leq 0.001$ was also adopted, and it was noted that the depressed subjects of Group A showed improvements in the parameters evaluated similar to the non-depressed subjects of the same group; while in Group B, the depressed elderly were able to reach a significant improvement after 12 months of exercises (Figures 5 and 6), in which Group A: black - not depressed, and white - depressed; and in Group B: stripped - not depressed and dots depressed.

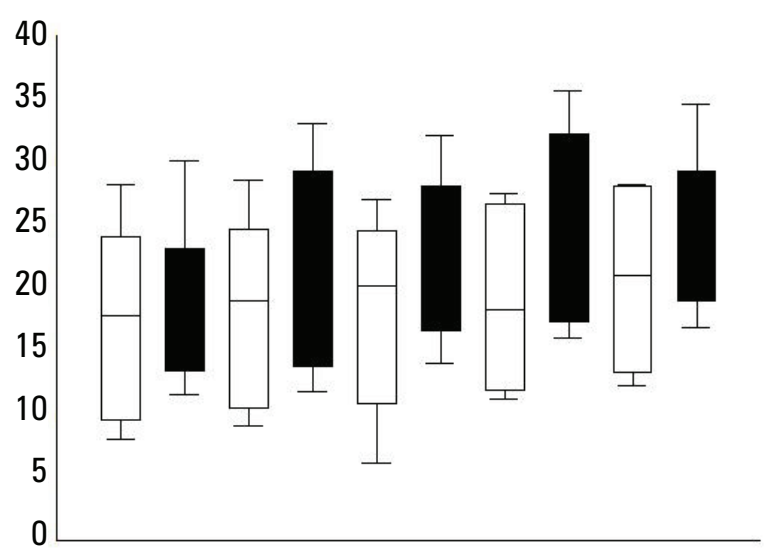

Figure 5. Flexibility test "Modified Wells Bench" Group A

In the intra-groups analysis, it was noted that $\mathrm{p}<0.001$, and the depressed elderly presented increased flexibility after 3 and 9 months.

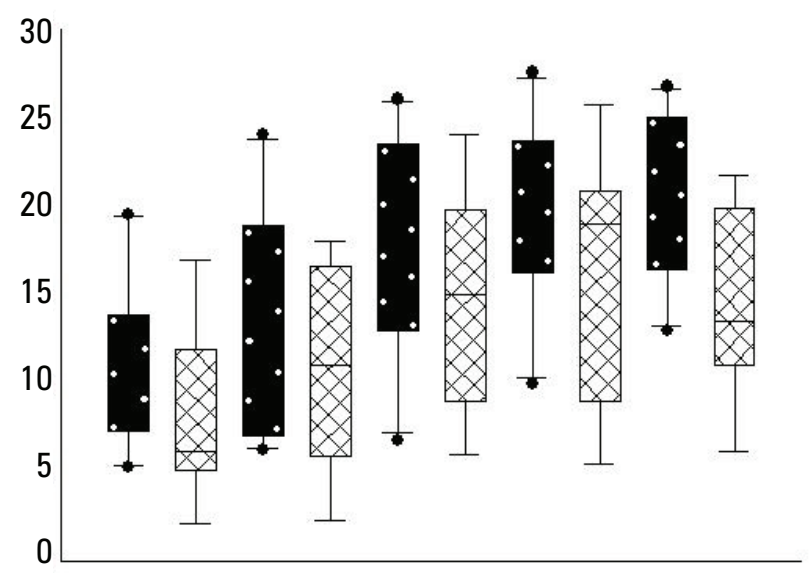

Figure 6. Flexibility test "Modified Wells Bench" Group B

In the intra-groups analysis, $\mathrm{p}<0.001$ was considered, and the depressed elderly showed increased flexibility after 3, 6, and 9 months.

In both groups, in the intra-groups analysis, it was noted that $\mathrm{p}<0.001$, and the depressed elderly subjects 
showed enhanced flexibility after 3 and 9 months (Group A) and after 3, 6, and 9 months in Group B. In Group A, the improvement was superior to that of nondepressed aged subjects.

In the inter-groups analysis, $\mathrm{p} \leq 0.001$ was considered, where the depressed subjects of Group A obtained a response superior to that of non-depressed subjects from both groups.

\section{DISCUSSION}

In the present study, it was demonstrated that wellsupervised physical exercises improve the functional capacity of the elderly with major depression, especially in terms of balance and flexibility. This observation was more expressive in the elderly subjects of Group A, who engaged in aerobic exercises.

It is worth pointing out that both groups were composed of depressed and non-depressed elderly subjects, divided by a raffle at the beginning of the study.

Many studies have highlighted the importance of the practice of physical exercise in improving and maintaining depressive symptoms, especially aerobic exercises, by the increased release of neurotransmitters and activation of specific receptors, helping to reduce scores indicative of depression and anxiety ${ }^{(4,17)}$. However, we did not find many studies with references to improvement of the functional capacity of elderly individuals with depression.

In the present study, it can be observed that depressed elderly subjects responded positively to physical exercise programs as much as non-depressed elderly do. This finding is extremely important in the rehabilitation of aged individuals with major depression.

Supervised regular practice of physical exercises helps the function of these elderly persons, decreasing complications related to sedentarism and immobilism, which are so common in depressive symptoms.

Simple physical activity, such as walking, helps to recover physical conditioning in the elderly, besides the fact that these individuals show an interesting improvement in muscular strengthening of the feet and lower limbs ${ }^{(18)}$. From the population point of view, a daily walk for 40 to 60 minutes is the simplest and most low-cost exercise possible, which can be easily incorporated into routine ${ }^{(19)}$. The present investigation observed that walking alone, in the elderly with major depression, incremented the parameters of equilibrium and flexibility, and the latter parameter was superior to that of non-depressed individuals in both groups.

Training composed of flexibility and equilibrium exercises (Group B) demonstrated a significant improvement in the parameters studied, but its results were not superior to those obtained in Group A.
Group B presented an average age of the non-depressed and depressed elderly individuals superior to the average of all the individuals of Group A. This may have been one of the factors of the results obtained. However, there is evidence that the improvement of the parameters of motor aptitude of aged adults does not depend on age ${ }^{(20)}$.

In this study, it is clear that both groups presented improvements in balance and flexibility, but that Group A obtained an improvement similar to those elderly who are not depressed. It was also observed that the association of physical exercises should be discussed in rehabilitation programs of elderly patients with major depression.

\section{CONCLUSION}

With the analysis of the results, it was possible to conclude that walking in an open environment, with irregular terrain, enables significant improvement in flexibility and equilibrium in elderly individuals with major depression.

Specific exercises (for equilibrium and flexibility) did not attain the same response found in the group that engaged in aerobic exercises, and was not effective for this group of aged individuals.

According to what was exposed, the present study highlights the importance of engaging in physical exercises, especially walking in an open environment, in order to improve balance and flexibility, thus decreasing the risk of comorbidities related to sedentarism and immobilism so frequent in elderly individuals with major depression.

The insertion of well-structured programs of physical exercises should be discussed and implanted in the treatment for major depression in the elderly.

\section{REFERENCES}

1. Veras R. Envelhecimento populacional contemporâneo: demandas, desafios e inovações. Rev Saúde Pública. 2009;43(3):548-54.

2. Veras RP, Murphy E. The mental health of older people in Rio de Janeiro. Int $J$ Geriatr Psychiatry. 1994;9(3):285-95.

3. Bottino CM, Ávila R, Moscoso MA, Ribeiz S, Pinto Junior JA, Jaluul 0. Influence of education and depressive symptoms and cognitive function in the elderly. Int Psychogeriatr. 2009;21(3):560-7.

4. Cheik NC, Reis IT, Heredia RA, Ventura ML, Tufik S, Antunes HK, et al. Efeitos do exercício físico e da atividade física na depressão e ansiedade em indivíduos idosos. Rev Bras Cir Mov. 2003;11(3):45-52.

5. Pedrinelli A, Garcez-Leme LE, Nobre RS. 0 efeito da atividade física no aparelho locomotor do idoso. Rev Bras Ortop. 2009;44(2):96-101.

6. Gusmão L, Campos GB. Exame neurológico - bases anátomo-funcionais. Rio de Janeiro: Revinter; 1992.

7. Maki BE. Gait changes in older adults: predictors of falls or indicators of fear? J Amer Geriatr Soc. 1997;45(2):313-20. 
8. Ostrosky KM. A comparison of gait characteristics in young and old subjects. Phys Ther. 1994;74(7):637-46.

9. Stella F, Gobbi S, Corazza DI, Costa JR. Depressão no idoso: diagnóstico, tratamento e benefícios da atividade física. Motriz (Rio Claro). 2002;8(3):91-8.

10. Okuma SS. 0 idoso e a atividade física. 2a ed. São Paulo: Papirus; 2002.

11. Pescatello LS, Di Pietro L. Physical activity in older adults. An overview of health benefits. Sports Med. 1993;15(16):353-64.

12. Puggaard L, Pedersen HP, Sandager E, Klitgaard H. Physical conditioning in elderly people. Scand J Med Sci Sports. 1994;4(1):47-56.

13. Guralnik JM, Ferrucci L, Simonsick EM, Salive ME, Wallace RB. Lowerextremity function in persons over the age of 70 years as a predictor of subsequent disability. New Engl J Med. 1995;332(9):556-60.

14. Fleming KL, Evans JM, Weber DC, Chutka DS. Pratical functional assessment of elderly persons: a primary-care approach. Mayo Clin Proc. 1995;70(9):890-910.
15. Hoeger WW, Hopkins DR. A comparison of the sit and reach and the modified sit and reach in the measurement of flexibility in women. Research Quart Exerc Sport. 1992;63(2):191-5.

16. Christmas C, Andersen RA. Exercise and older patients: guidelines for the clinician. J Am Geriatr Soc. 2000;48(3):318-24.

17. Meeusen R, Demeirleir K. Exercise and brain neurotransmission. Sports Med. 1995;20(3):160-88.

18. Barbosa RM. Educação física e suas indicações. Educação física gerontológica. Saúde e qualidade de vida na terceira idade. Rio de Janeiro: Sprint; 2000.

19. Carvalho-Filho ET. Medicina preventiva no idoso. Rev Bras Clín Terap. 2003;29(1):8-16.

20. Lanuez FV, Jacob-Filho W. Effect of two programs of physical exercise in the motor fitness of sedentary elderly subjects. einstein. 2008;6(1): 76-81. 